\title{
PERCEPTION OF HYPERTENSION PATIENTS ON TREATMENT IN TAMIANG LAYANG HOSPITAL, CENTRAL KALIMANTAN, INDONESIA
}

\section{Theresia Jamini ${ }^{\text {** }}$ \\ Putri Perdana Anggreni $^{2}$ \\ Dwi Marta Agustina ${ }^{3}$ \\ ISTIKES Suaka Insan \\ Banjarmasin, Banjarmasin, \\ Kalimantan Selatan, Indonesia \\ 2STIKES Suaka Insan \\ Banjarmasin, Banjarmasin, \\ Kalimantan Selatan, Indonesia \\ 3STIKES Suaka Insan \\ Banjarmasin, Banjarmasin, \\ Kalimantan Selatan, Indonesia \\ *email: star.chr@gmail.com}

\section{Kata Kunci:}

Persepsi

Hipertensi

Pengobatan Hipertensi

\section{Keywords:}

Perpection

Hypertension

Hypertension Treatment

\begin{abstract}
Abstrak
Masalah hipertensi merupakan masalah yang sangat penting mengingat komplikasi yang ditimbulkannya. Tujuan penelitian untuk mengetahui gambaran persepsi pasien hipertensi terhadap pengobatannya di instalasi rawat inap RSUD Tamiang Layang tahun 2019.

Metode penelitian kuantitatif dengan rancangan penelitian deskriptif. Pengambilan sampel dengan non probabality sampling yaitu purposive sampling yang berjumlah 30 responden. Proses pengumpulan data dengan menggunakan intrumen kuesioner.

Data yang diperoleh kemudian diolah dan dianalisis dengan menggunakan Analisis Univariat.

Hasil penelitian menunjukkan sebanyak $93,33 \%$ responden memiliki klasifikasi persepsi positif terhadap pengobatannya, dan sebanyak $6,67 \%$ resonden memiliki klasifikasi persepsi negatif. Disimpulkan bahwa persepsi pasien hipertensi terhadap pengobatannya di ruang rawat Inap di RSUD Tamiang Layang tahun 2019, memiliki klasifikasi positif terhadap pengobatannya, yang artinya sebagian besar pasien mengetahui dan memahami tentang pengobatan hipertensi secara farmakologi dan non farmakologi walaupun masih belum optimal.
\end{abstract}

\begin{abstract}
Hypertension is a significant health problem considering the complications it causes. The research objective was to describe hypertensive patients' perceptions of their treatment at the inpatient installation of RSUD Tamiang Layang in 2019.

Quantitative research methods with descriptive research design were applied with sampling with non-probability sampling is purposive sampling, amounting to 30 respondents - the process of collecting data using a questionnaire instrument.

The data obtained were then processed and analyzed using Univariate Analysis.

The results showed that $93.33 \%$ of respondents had a positive perception classification of their treatment, and as many as $6.67 \%$ of respondents had a negative perception classification. It was concluded that the perception of hypertensive patients towards treatment in the inpatient room at RSUD Tamiang Layang in 2019, has a positive classification of treatment, which means that most patients know and understand hypertension treatment both pharmacologically and non-pharmacologically, although it is still not optimal.
\end{abstract}

(C) year The Authors. Published by Institute for Research and Community Services Universitas Muhammadiyah Palangkaraya. This is Open Access article under the CC-BY-SA License (http://creativecommons.org/licenses/by-sa/4.0/). DOI: https://doi.org// 0.33084/jsm.vxix.xxx.

\section{PENDAHULUAN}

Hypertension is a very important health problem considering the complications it causes. Hypertension is a complex condition in which blood pressure is consistently above normal. The criteria for hypertension used in case determination refer to the JNC VII 2003 diagnostic criteria, namely the measurement results of systolic blood pressure $\geq 140 \mathrm{mmHg}$ or diastolic pressure $\geq 90 \mathrm{mmHg}$ (Riskesdas, 2013). The 2016 National Health Indicator Survey (Sirkesnas) states that the percentage of the population with hypertension has increased to 32.4 percent (Kementrian Kesehatan RI. 2016). The 2018 basic health research conducted by the Health Research and Development Agency for the Ministry of Health, found that hypertension was the first ranked in the top 10 diagnoses of noncommunicable diseases, totaling 185,857 cases. 
Based on the 2016 Central Kalimantan Provincial Statistics Agency, hypertension is in the second rank after influenza in the 10 most cases of the disease in Central Kalimantan with 4I,819 cases. East Barito Regency is one of the districts in Central Kalimantan with a total population of 120,254 inhabitants in 2017, consisting of 61,692 men and 58,292 women with a population density of 31.37 people $/ \mathrm{km}$. In one of the hospitals in Central Kalimantan, RSUD Tamiang Layang is the only hospital in East Barito, Central Kalimantan Province. From patient visits at RSUD Tamiang Layang, hypertension was ranked the 10th most outpatient disease in 2016 with 280 cases. Meanwhile, inpatient visits were in second place, with 145 cases. In 2017 the number of outpatient visits to hypertension patients was 320 cases, while inpatients were 106 cases. In 2018 there was an increase in the number of hospitalized cases to 290 cases. They consisted of 257 cases of primary hypertension and 33 cases of secondary hypertension, with repeated visits as many as 188 cases. Most cases were 40-60 years old 154 cases and II2 cases aged 60-80 years (RSUD Tamiang Layang, 2018).

The management of hypertension can be undertaken by means of pharmacological and non-pharmacological therapies. In previous studies, it was found that the factors that influenced the management of hypertension were the last education level, the length of time suffering from hypertension, the level of knowledge about hypertension, family support, the role of health workers and motivation for treatment (Cahyaningtyas, 2012; Evadewi and Sukmayanti. 2013; Puspita, 2016). The patient's attitude towards hypertension affects motivating the patient to manage the disease. Family supervision as a form of support in the form of recommendations/low-salt food intake, exercise (healthy walking, exercise, jogging), reminding to take medication regularly (Ayu Martiani, 2012). Knowledge of patients plays an important role in shaping patients' behavior and actions based on daily life experiences and other people. The patient's length of time suffers from hypertension affects the patient's physiology because of the long-term use of drugs, which can cause side effects to organ damage and psychologically cause feelings of boredom or saturation of consuming drugs every day. Patient factors influence compliance with taking medication, health system factors including health workers, health financing, easy access to drugs prescribed by the pharmacy, the role of health workers as information providers to patients, ownership of health insurance, drug distribution, good interactions between patients and medical personnel, environmental factors and socio-economic factors (Adib, 2009; Ahmad, 20II; Hulaima, 2017). Adherence can be used as a parameter for patient knowledge in carrying out instructions from medical personnel in the form of knowledge of prescriptions, taking the medication regularly, and appropriately and changing lifestyle. The goal of treatment for hypertension sufferers is to improve the quality of life, but many stop treatment when their bodies are slightly better, so compliance with patients undergoing hypertension treatment is needed to obtain a better quality of life for patients. In addition, according to Wibawa (2008) in his research, factors that influence patient compliance in treatment include education level, knowledge level, income level, ease of accessing health facilities, and the availability of health insurance that relieves patients from paying medical expenses.

Based on interviews with 10 inpatients in the inpatient room of Tamiang Layang Regional Hospital on March 4, 2019 to March 6, 2019, it was found that the patient's perception of hypertension treatment as recommended by health workers was 7 (70\%) respondents aged 40-60 years said they did not take medicine because they felt they had no complaints or felt healthy so they did not need to take medicine or go to a health service, 2 people $(20 \%)$ of respondents aged $40-60$ years said that when traveling they forgot to bring medicine, I person $(10 \%))$ said he was tired of taking medicine because the doctor recommended that he take medicine every day. 
This study aimed to examine the perceptions of hypertensive patients on their treatment at the inpatient installation of RSUD Tamiang Layang in 2019.

\section{METODOLOGI}

In this study, a quantitative method is used, namely, a method based on the philosophy of positivism, which is used to examine a particular population or sample, and the sampling technique is carried out randomly (Arikunto, 2009). Collecting data using questionnaire or interview as research instruments, data analysis is quantitative / statistical with the aim of testing the predetermined hypothesis (Sugiyono, 2015; Sugiyono, 2016). A descriptive research design is a research method used to describe or analyze a research result but without intending to make broader conclusions (Sugiyono, 2013).

The variable used in this study was the patient's perception of hypertension as a single variable. This research will be conducted in the inpatient room, namely the Bougenville room, Mawar room, Tulip room, Anggrek room, Aster room, Melati room, Edelweiss room, at RSUD Tamiang Layang from June 20, 2019 - August 03, 2019.

The sampling technique used was non-probability sampling, namely, purposive sampling. The population in this study were recurrent hypertension patients who had been treated with a previous diagnosis of hypertension based on the medical record data of RSUD Tamiang Layang, data on recurrent inpatient hypertension patients at RSUD Tamiang Layang from January to December 2018 totaling 188 people. The sample in this study was all patients who repeated at the Inpatient Installation of the RSUD Tamiang Layang, totaling 30 people, the minimum number of samples. Sampling was based on inclusion and exclusion criteria. The inclusion and exclusion criteria in this study include:

I. Inclusions:

a. patients who are willing to be respondents b. Cooperative patient / good level of consciousness

c. Patients who were re-treated for hypertension

d. Patients $>20$ years of age

2. Exclusion:

a. Hypertensive patients who have other diseases (complications).

b. Patients with impaired senses of sight, hearing,

c. Patients who cannot read (illiterate).

In this study, the instrument used was a questionnaire containing 23 statements of individual perceptions about their treatment. The analysis was performed using univariate analysis. This analysis was conducted to describe the patient's perception of adherence to taking antihypertensive drugs.

\section{HASIL DAN PEMBAHASAN}

\section{Respondent Characteristics}

This study's respondents' characteristic data are presented in Table I-8, including age, gender balance, education level, occupation, medical expenses, duration of suffering from hypertension, blood pressure control, and history of hypertension. In terms of age, most hypertension sufferers are aged over 45 years, namely 46-55 years, 66-75 years, and 56-65 years and some of these hypertensive sufferers are female. The education level of respondents, most of them are high school graduates or equivalent, while the occupation of most people with hypertension is housewives. The length of time the respondents have suffered from hypertension is mostly between I-5 years, while the cost of treatment generally comes from the BPSS and is followed by their expenses.

Table I. Age of respondent

\begin{tabular}{|c|c|c|c|}
\hline No & Age & $\mathrm{N}$ & $\%$ \\
\hline $\mathrm{I}$ & $26-35$ year & 4 & 13.33 \\
\hline 2 & $36-45$ year & 3 & 10 \\
\hline
\end{tabular}




\begin{tabular}{|c|c|c|c|}
\hline 3 & $46-55$ year & 8 & 26.67 \\
\hline 4 & $56-65$ year & 7 & 23.33 \\
\hline 5 & $66-75$ year & 8 & 26.67 \\
\hline \multicolumn{2}{|c|}{ Total } & 30 & 100 \\
\hline
\end{tabular}

Ucapan terima kasih kepada seluruh sivitas akademika yang telah membantu dalam proses Penelitian. Enumerator Penelitian yang meluangkan waktu dalam pengumpulan data. Instansi Rumah sakit sebagai tempat penelitian yang telah memberikan kesempatan.

Table 2. Gender of Respondent

\begin{tabular}{|c|c|c|c|}
\hline No & Gender & N & $\%$ \\
\hline $\mathrm{I}$ & Male & 8 & 26.67 \\
\hline 2 & Female & 22 & 73.33 \\
\hline \multicolumn{2}{|c|}{ Total } & 30 & 100 \\
\hline
\end{tabular}

Table 3. Education Level of Respondent

\begin{tabular}{|c|c|c|c|}
\hline No & High Education & F & $\%$ \\
\hline I & No School & 0 & 0 \\
\hline 2 & $\begin{array}{c}\text { Did not complete } \\
\text { Elementary } \\
\text { School/equivalent }\end{array}$ & 0 & 0 \\
\hline 3 & $\begin{array}{c}\text { Completed Elementary } \\
\text { School / equivalent }\end{array}$ & 0 & 0 \\
\hline 4 & $\begin{array}{c}\text { Completed Junior High } \\
\text { School / equivalent }\end{array}$ & 5 & 16.67 \\
\hline 5 & $\begin{array}{c}\text { Graduated from high } \\
\text { school / equivalent }\end{array}$ & 15 & 50 \\
\hline 6 & University & 10 & 33.33 \\
\hline \multicolumn{2}{|c|}{ Total } & 30 & 100 \\
\hline
\end{tabular}

\section{KESIMPULAN}

Kekuatan gengaman tangan pada penderita post stroke termasuk dalam kriteria kurang sekali ( $<13,5 \mathrm{Kg}$ ). ada hubungan usia dengan kekuatan otot pasca Stroke ( $P$ value 0.023) dan semakin bertambah umur maka kekuatan otot berkurang. Perlu dilakukan perbaikan fungsi lengan dengan berbagai metode diantaranya latihan rentang gerak, latihan penguatan dan latihan gengam bola selama di Rumah maupun Rumah Sakit. Peneliti selanjutnya dapat melakukan uji coba pada intervensi tersebut untuk melihat pengaruhnya bagi peningkatan kekuatan otot pasien.

\section{REFERENSI}

I. Aditmika \& Santika. 20I5. Tes dan pengukuran jasmani \& Olahraga. Solo : TB Rahma

2. American Heart Association (AHA). 2010. Adult Basic Life Support : Guidelines for CPR and Emergency Cardiovascular Care, http://circ.ahajournals.org/content//22//8_suppl_ $\underline{3 / S 685}$

3. Black, M. J \& Hawks, H. J. 2009. Medical Surgical Nursing : Clinical management for Continuitu of Care, 8th ed. Philadelphia : WB Sounders Company.

4. Goldszmidt A J \& Caplan LR .2013. Stroke Essential Vol 2. PT Indeks

5. Kemenkes . 2018. Hasil utama Riset Kesehatan Dasar. Jakarta. Jakarta. Badan penelitian dan pengembangan Kesehatan Kementerian Kesehatan.

6. Prog W, Gessal J, Angliadi .2016. Pengaruh Latihan Gerakan Aktif menggenggam Bola pada Pasien Stroke di Ukur menggunakan Handgrip Dynamometer. Jurnal E-Clinic. Vol 4 (I) : 7 I - 75

7. Sions, J.M. Tyrell CM, Knarr BA, Jancosko A, Binder-Macleod SA, 2012. Age and Stroke Related Skeletal Muscle Changes : A Review for The Geriatric Clinician. Journal Geriatr Phys Ther. 35 (3) : I55-16|

8. Saunder, D.H, Greig CA, Mead GE .20I4. Physical Activity and Exercises After Stroke Review of Multiple Meanigful benefits. Stroke American Hearth Association. 45 ( I2) : 3742 -374I 
9. Smelzer SC \& Bare BG . 2008. Buku Ajar kesehatan Medikal Bedah, Volume 2, Edisi 8 jakarta. Buku Kedokteran EGC.

10. Soohee \& Joo-Young ( 2016) Grip Strength in post Stroke hemiplegia. The Journal of Physical Therapy Science 28 : 677-679

II. Stock R., Thrane G., Askim T., Ankle A, Mork PJ., 2019. Development of Grip Strength During The First year After Stroke. Jurnal Rehabilitation Medicine 5 I (I-9) 